\title{
Boter op je hoofd
}

JOB VAN AMERONGEN

'G eef het maar eerlijk toe. Je hebt ze hoogstpersoonlijk uit mijn ijskast gejat.' Totaal verbouwereerd staar ik mevrouw Kraamer aan. Ze wijst naar drie pakjes roomboter in de centrale koelkast op huiskamer 7. 'In de nacht sluip je mijn kamer binnen, haalt boter en kaas uit mijn ijskast en legt die hier neer. Achter die donkerbruine ogen gaat een keiharde persoonlijkheid schuil.' Ik overweeg een weg te bewandelen waarvan ik vooraf eigenlijk al weet dat die doodlopend is: mevrouw Kraamer ervan overtuigen dat ik nog nooit iets gestolen heb en me ook nimmer op onchristelijke tijdstippen binnen Nieuw Vredeveld ophoud. Maar ik krijg de kans niet eens. 'En van haar en hem zal je ook wel de nodige spullen hebben ontvreemd,' vervolgt mevrouw Kraamer onstuitbaar haar tirade.

De andere 'benadeelden', mevrouw Van Dijk en meneer Jansen, blijken echter niet wantrouwend van aard en kiezen partij voor de beschuldigde. Daarbij hebben ze zo hun eigen stijl. Meneer Jansen reageert met: 'Ziet hij er uit als een dief dan?' en doet daarmee een beroep op de ratio waardoor ik me zeer gevleid voel. Fijn dat er in ieder geval nog iemand is bij wie mijn donkerbruine ogen vertrouwen inboezemen. Mevrouw Van Dijk, die al ruim elf jaar deze huiskamer met mevrouw Kraamer deelt, pakt het heel anders aan en kiest de frontale aanval. Dat mensen naar elkaar toegroeien naarmate ze elkaar langer kennen, blijkt maar al te vaak een theorie met in de praktijk een wankele basis. 'Een gestoord wijf, dat ben je,' bijt ze mevrouw Kraamer toe. 'Van de week

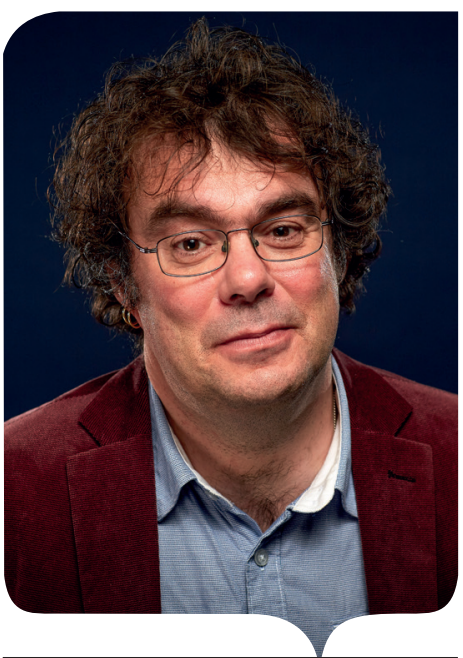

え Job van Amerongen werkt als verpleegkundige op de dagbesteding voor jonge mensen met dementie 'De Luwte' van de Zonnehuisgroep in Amstelveen en als projectverpleegkundige dagbesteding voor 'Nieuw Vredeveld'van Stichting Brentano, ook in Amstelveen.

riep je al dat de kok expres geen ballen in je soep had gedaan en nou zal hij daar drie armzalige pakjes roomboter van je hebben weggenomen. Nou, ze verdienen hier niet veel, maar een pakje roomboter valt nog best te bekostigen. Je moet je eens goed laten nakijken! En totdat je dat gedaan hebt hier niet meer in de huiskamer verschijnen!' De beschuldigde zelf heeft ondertussen nog geen verbale duit in het zakje kunnen doen en staart glazig naar drie kuipjes roomboter in de koelkast. 'Roomboter maakt alles beter' staat er op de verpakking. Het lijkt me een nogal ongenuanceerde uitspraak, maar tijd om deze slogan eens uitgebreid op zijn merites te beoordelen is er niet. De messen voor verdere confrontatie zijn geslepen. 'Jullie zitten allemaal in het complot,' briest mevrouw Kraamer terwijl ze de huiskamer stampvoetend verlaat en de deur hard dichtslaat. 'Opgeruimd staat netjes,' zo vindt mevrouw Van Dijk. Ik moet erkennen die primitieve emotie van harte met haar te delen, maar de zorgverlener in mij zegt dat ik mevrouw Kraamer in bescherming moet nemen. En dus probeer ik het met: 'Voor mevrouw Kraamer is het zelf ook heel naar dat ze soms zo achterdochtig is,' 'Mevrouw Kraamer kan daar niets aan doen' en 'Het leven heeft mevrouw Kraamer ook niet altijd toegelachen.' Terwijl ik het zeg, stel ik mezelf al de vraag waarom ik toch iedere keer mijn toevlucht neem tot dergelijke goedwillende zinsneden. De bodem voor deze zaadjes van empathie is immers hard en stenig, althans in het geval van mevrouw Van Dijk. Nu is het haar beurt om boos de huiskamer te verlaten. 'Wat een dom gezwets van je. Dat mens weet drommels goed wat ze zegt. Je bent ook een waardeloze vent. Laat je eerst uitschelden en neemt het dan ook nog op voor dat stuk verdriet. Totaal karakterloos, dat ben je.' In de huiskamer blijf ik achter met meneer Jansen. 'Kopje koffie?' informeert hij. De dynamiek van de morgen geeft mijn antwoord een diepgevoelde overtuiging mee: 'Heel graag!' 